\title{
Assessing the heavy metal pollution level in Jiu Valley by bio-monitoring inferior plants - moss
}

\author{
Andrei Szollosi-Moța ${ }^{*}$, Maria Prodan, Irina Vasilica Nălboc, and Sonia Niculina Șuvar \\ National Institute for Research and Development in Mine Safety and Protection to Explosion - \\ INSEMEX, 32-34 G-ral Vasile Milea street, 332047, Petrosani, Hunedoara county, Romania
}

\begin{abstract}
The analysis of the samples collected from residential areas and the proximity of the industrial areas of Jiu Valley was carried out by means of induced coupled plasma optical emission spectrometry (ICP-OES) after acid processing and mineralization of the samples. The pollution level has increased once with the industrial development and acceleration of urbanization processes in the human society. Of the pollutant-generating substances, heavy metals are of particular importance. The purpose of this paper is to highlight level of pollution by heavy metals using moss (inferior plants) in order to determine the degree of bioaccumulation. From the pollution point of view, zinc, cadmium and lead are of particular relevance, but the effects of other heavy metals have also been studied. The pollution effects last for a long time in waste dumps, areas polluted with heavy metals from fuel combustion processes, fossil fuels a.s.o. The analysis of the samples collected from residential areas and the proximity of the industrial areas of Jiu Valley was carried out by means of induced coupled plasma optical emission spectrometry (ICP-OES) after acid processing and mineralization of the samples.
\end{abstract}

\section{Introduction}

Due to their excellent properties as bio-indicators, some plants, such as moss and lichens, can be used to determine the degree of accumulation of pollutants. Mosses accumulate heavy metals to a greater extent than flower plants, including rare elements that are not detectable in the substrate [1]. Because they have no cuticle and thick cell walls, their cells are readily permeable to water and minerals (including contaminants such as metals), so that the substances are also taken from precipitations and materials deposited on their surface, transported by air [2].

The amount of accumulated elements is determined by the concentration of elements in atmospheric sedimentation, the surface of the mosses, the adsorption capacity and the ion exchange capacity [3] The elemental composition of the substrate has an effect on endocrine species with internal water transport system, but is negligible in the case of ectohydric species in which water is transported over the outer surface of the moss (e.g.: Hypnum). [4].The use of mosses for bio-indication purposes can be performed on one hand

* Corresponding author: andrei.szollosi@insemex.ro 
by inventing the occurrence of species found in situ in the area investigated and by studying their chemical composition. Thus, the most widespread use of mosses as bio-indicators may be that of determining the heavy metal load. [5] By their chemical analysis, there have been determined the area which are contaminated more.

That besides industrial production, road transport is also the second largest source of pollution. More and more cars appear each year, along with more heavy metals $(\mathrm{Zn}, \mathrm{Pb}, \mathrm{Cd}$, $\mathrm{Ni}, \mathrm{Cr}, \mathrm{Cu}$ ) and many other substances that are very harmful to health are released into the air [6].

The bedrock may appear in the solid phase as mineral constituents (interchangeably, or they can specifically adsorb to soil colloids; they are often formed with some anions precipitation, e.g. carbonate, phosphate [7]. In the solid phase of the soil the role of soil colloids is outstanding. A fraction having a particle size of 1 to $500 \mathrm{~nm}$ is considered a size range of soil colloids $[8,9]$.

Swaileh et.al. identified at a metal content of $149 \mathrm{mg} / \mathrm{kg}$ in soil, and in plants from the soil of only $2.19 \mathrm{mg} / \mathrm{kg}$ [7]. Heavy metals are present in both the solid and liquid phases of soil, where they are can create a variety of bonding patterns.
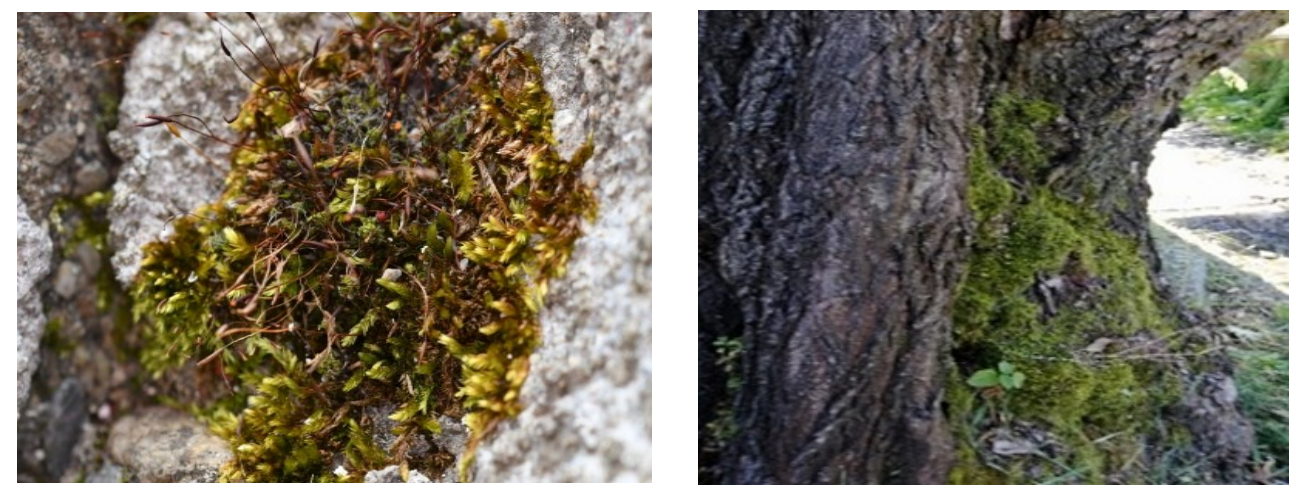

Fig. 1. Moss photography - Tortura muralis
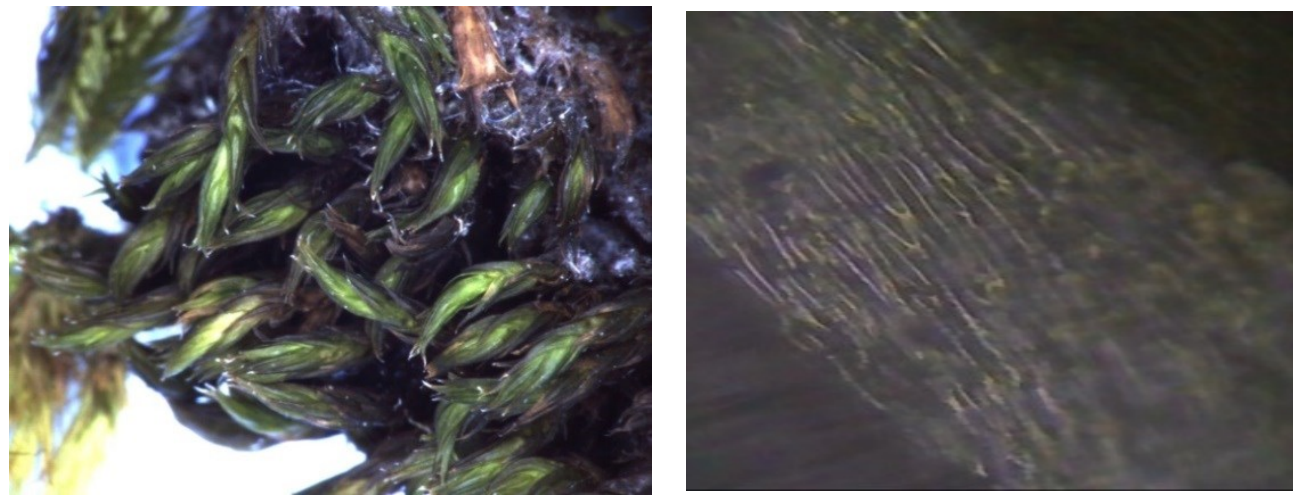

Fig. 2. Moss photography - Tortura muralis - microscopic imagines

\section{Material and method}

In Jiu Valley, industry is mainly characterized by the activity of the mining industry, even if the extraction of coal and the related industry has restricted its activity in the last decades. The production of electric and thermal energy by combustion of fossil fuels along with 
transportation is an important source of air, soil and water contamination with heavy metals. Elements selected for study are cadmium, lead, nickel, zinc, cobalt, copper, arsenic. The sampling took place in the residential areas of Jiu Valley, but also near the industrial units.

It was sought to cover models around crowded roads, junctions and others less crowded points, industrial units, but also in areas more distant and less susceptible to pollution. The used Inductively Coupled Plasma analysis method, is a method of optical emission spectrometry. When plasma energy is given to an analysis sample from outside, the component atoms are given a superior energy form. When the atoms return to low energy position, spectrum are released and the emission rays that correspond to the photon wavelength are determined.

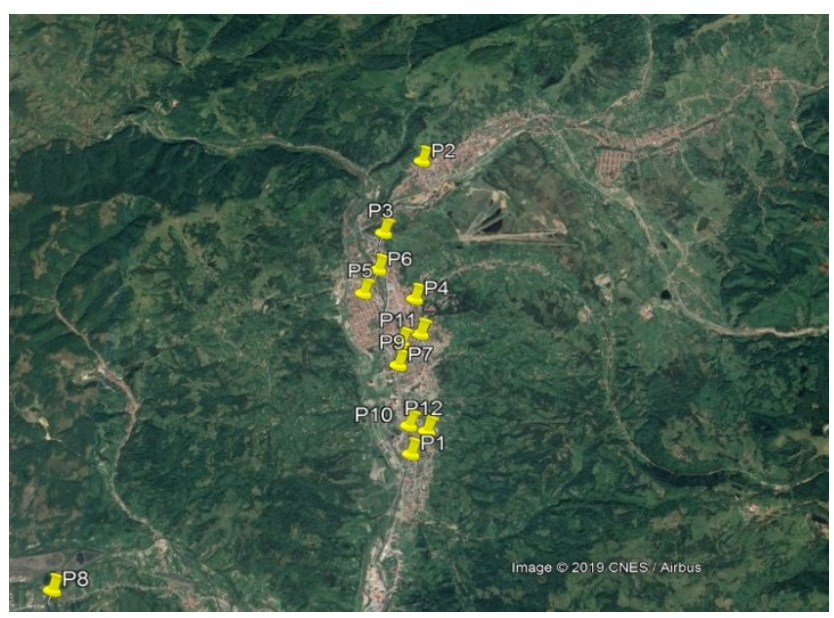

Fig. 3. Sampling points of the moss samples in The Jiu Valley $(\mathrm{P} 1 \div \mathrm{P} 12)$

Table 1. Sampling point of the moss samples

\begin{tabular}{|c|c|c|}
\hline Sampling point & Sampling area description & Coordinates \\
\hline $\mathrm{P} 1$ & Approaching rail and road E66 & $\begin{array}{l}45^{\circ} 23^{\prime} 54.21 " \mathrm{~N} \\
23^{\circ} 22^{\prime} 36.29^{\prime \prime} \mathrm{E}\end{array}$ \\
\hline $\mathrm{P} 2$ & Petrila - the main road & $\begin{array}{l}45^{\circ} 26^{\prime} 33.36^{\prime \prime} \mathrm{N} \\
23^{\circ} 22^{\prime} 20.52^{\prime \prime} \mathrm{E}\end{array}$ \\
\hline P3 & Road E66 IUMP Area & $\begin{array}{l}45^{\circ} 25^{\prime} 46.44^{\prime \prime N} \\
23^{\circ} 21^{\prime} 56.47^{\prime \prime} \mathrm{E}\end{array}$ \\
\hline P4 & $\begin{array}{l}\text { Approximation of general } \\
\text { school no. } 4\end{array}$ & $\begin{array}{l}45^{\circ} 25^{\prime} 07.86^{\prime \prime} \mathrm{N} \\
23^{\circ} 22^{\prime} 21.95^{\prime \prime} \mathrm{E}\end{array}$ \\
\hline P5 & Colony & $\begin{array}{l}45^{\circ} 25^{\prime} 12.20^{\prime \prime N} \\
23^{\circ} 21^{\prime} 44.96^{\prime \prime} \mathrm{E}\end{array}$ \\
\hline P6 & CFR Train Station & $\begin{array}{l}45^{\circ} 25^{\prime} 25.86^{\prime \prime N} \\
23^{\circ} 21^{\prime} 52.45^{\prime \prime} \mathrm{E}\end{array}$ \\
\hline P7 & Stadium area & $\begin{array}{l}45^{\circ} 24^{\prime} 31.84^{\prime \prime N} \\
23^{\circ} 22^{\prime} 11.48^{\prime \prime} \mathrm{E}\end{array}$ \\
\hline P8 & The main road & $\begin{array}{l}45^{\circ} 24^{\prime} 49.00^{\prime \prime} \mathrm{N} \\
23^{\circ} 22^{\prime} 27.10^{\prime \prime} \mathrm{E}\end{array}$ \\
\hline P9 & Central Park Carol Schreter & $\begin{array}{l}45^{\circ} 24^{\prime} 49.52^{\prime \prime N} \\
23^{\circ} 22^{\prime} 27.68^{\prime \prime} \mathrm{E}\end{array}$ \\
\hline P10 & The Livezeni railway & $45^{\circ} 23^{\prime} 51.24^{\prime \prime} \mathrm{N}$ \\
\hline
\end{tabular}




\begin{tabular}{|c|c|c|}
\hline & & $23^{\circ} 22^{\prime} 19.22^{\prime \prime} \mathrm{E}$ \\
\hline \multirow{2}{*}{ P11 } & Dimitrov neighbourhood & $\begin{array}{l}45^{\circ} 23^{\prime} 51.24 " \mathrm{~N} \\
23^{\circ} 22^{\prime} 19.22^{\prime \prime} \mathrm{E}\end{array}$ \\
\hline \multirow{2}{*}{ P12 } & Airport neighbourhood & $\begin{array}{l}45^{\circ} 23^{\prime} 43.09^{\prime \prime} \mathrm{N} \\
23^{\circ} 22^{\prime} 23.65^{\prime \prime} \mathrm{E}\end{array}$ \\
\hline
\end{tabular}

In figure no. 3 and table no. 1 are the sampling points and coordinates of the moss samples.

The moss and soil samples were taken and analyzed in June 2019.

\section{Results and discussion}

There have been collected dried and analysed moss samples by inductive coupled plasma spectrometry using the OPTIMA 2100 DV (ICP-OES) spectrometer. Concentrations of Co, $\mathrm{Cr}, \mathrm{Cu}, \mathrm{Ni}, \mathrm{Pb}, \mathrm{Zn}$ as found in moss samples $(\mathrm{P} 1 \div \mathrm{P} 12)$ are presented in Table 2. Soil samples $\mathrm{S} 13 \div \mathrm{S} 17$ were collected, mineralized and analysed.

For the analysis, the samples were subjected to acidification using high purity nitric acid at $170{ }^{\circ} \mathrm{C}$ and 12 bar pressure using the microwave mineralizer, the mineralization program lasting approximately 2 hours and 30 minutes.

Table 2. Concentrations of metal obtained from mosses samples analysis

\begin{tabular}{|c|c|c|c|c|c|c|c|c|c|}
\hline $\begin{array}{c}\mathbf{A s} \\
\mathbf{m g} / \mathbf{k g}\end{array}$ & $\mathbf{P 1}$ & $\mathbf{P 2}$ & $\mathbf{P 3}$ & $\mathbf{P 4}$ & $\mathbf{P 5}$ & $\mathbf{P 6}$ & $\mathbf{P 7}$ & P8 & P9 \\
\hline $\begin{array}{c}\mathbf{A s} \\
\mathbf{m g} / \mathbf{k g}\end{array}$ & 8.088 & 1.649 & 0.319 & 6.448 & 0.368 & 2.006 & 1.618 & 0.757 & 4.609 \\
\hline $\begin{array}{c}\mathbf{C d} \\
\mathbf{m g} / \mathbf{k g}\end{array}$ & 4.119 & 1.461 & 2.720 & 2.020 & 2.257 & 2.231 & 3.119 & 2.394 & 2.246 \\
\hline $\begin{array}{c}\mathbf{C o} \mathbf{m g / k g} \\
\mathbf{C r}\end{array}$ & 6.545 & 0.230 & 1.723 & 1.928 & 1.895 & 1.963 & 2.753 & 1.412 & 2.016 \\
\hline $\begin{array}{c}\mathbf{m g} / \mathbf{k g} \\
\mathbf{C u}\end{array}$ & 84.50 & 11.58 & 9.558 & 1.442 & 4.618 & 4.950 & 10.32 & 31.84 & 0.126 \\
$\mathbf{m g / k g}$ & 180.2 & 3.033 & 31.66 & 2.806 & 15.64 & 11.67 & 18.99 & 8.906 & 0.014 \\
$\begin{array}{c}\mathbf{N i} \\
\mathbf{m g} / \mathbf{k g}\end{array}$ & 50.88 & 0.080 & 6.301 & 0.318 & 3.833 & 4.181 & 4.480 & 1.017 & 0.371 \\
\hline $\begin{array}{c}\mathbf{P b} \\
\mathbf{m g} / \mathbf{k g}\end{array}$ & 45.98 & 0.045 & 9.971 & 3.060 & 7.385 & 3.162 & 14.84 & 1.620 & 10.86 \\
\hline $\begin{array}{c}\mathbf{Z n} \\
\mathbf{m g} / \mathbf{k g}\end{array}$ & 707.5 & 9.197 & 105.9 & 66.35 & 804.0 & 43.68 & 71.14 & 51.33 & 24.62 \\
\hline
\end{tabular}

Table 3. Concentrations obtained from the analysis of mosses samples and soil samples

\begin{tabular}{|c|c|c|c|c|c|c|c|c|}
\hline & $\mathbf{P 1 0}$ & $\mathbf{P 1 1}$ & $\mathbf{P 1 2}$ & $\mathbf{S 1 3}$ & $\mathbf{S 1 4}$ & $\mathbf{S 1 5}$ & $\mathbf{S 1 6}$ & $\mathbf{S 1 7}$ \\
\hline $\begin{array}{c}\mathbf{A s} \\
\mathbf{m g} / \mathbf{k g}\end{array}$ & 0.026 & 2.948 & 1.309 & 0.505 & 0.565 & 0.678 & 0.746 & 0.041 \\
\hline $\begin{array}{c}\mathbf{C d} \\
\mathbf{m g} / \mathbf{k g}\end{array}$ & 2.168 & 2.670 & 2.741 & 1.649 & 1.938 & 1.821 & 0.862 & 2.204 \\
\hline $\begin{array}{c}\mathbf{C o} \\
\mathbf{m g} / \mathbf{k g}\end{array}$ & 8.218 & 6.817 & 2.530 & 1.011 & 1.531 & 2.098 & 1.060 & 17.38 \\
\hline $\begin{array}{c}\mathbf{C r} \\
\mathbf{m g} / \mathbf{k g}\end{array}$ & 14.26 & 61.37 & 17.29 & 0.020 & 3.402 & 3.994 & 0.652 & 20.02 \\
\hline $\begin{array}{c}\mathbf{C u} \\
\mathbf{m g} / \mathbf{k g}\end{array}$ & 46.24 & 144.5 & 23.43 & 1.90 & 9.086 & 9.086 & 3.464 & 26.76 \\
\hline
\end{tabular}




\begin{tabular}{|c|c|c|c|c|c|c|c|c|}
\hline $\begin{array}{c}\mathbf{N i} \\
\mathbf{m g} / \mathbf{k g}\end{array}$ & 9.189 & 36.14 & 10.42 & 0.198 & 2.894 & 3.992 & 1.042 & 54.4 \\
\hline $\begin{array}{c}\mathbf{P b} \\
\mathbf{m g} / \mathbf{k g}\end{array}$ & 111.6 & 180.9 & 10.13 & 0.654 & 4.775 & 2.355 & 0.175 & 0.926 \\
\hline $\begin{array}{c}\mathbf{Z n} \\
\mathbf{m g} / \mathbf{k g}\end{array}$ & 464.1 & 568.0 & 747.1 & 8.248 & 602 & 35.11 & 22.58 & 106.8 \\
\hline
\end{tabular}

Following the analysis of the moss samples, in table 2 and 3, the highest concentrations of metals obtained were recorded in the case of zinc and copper. The heavy metal concentrations obtained from the analysis of the moss samples contain higher values of metals than the soil samples analyzed.

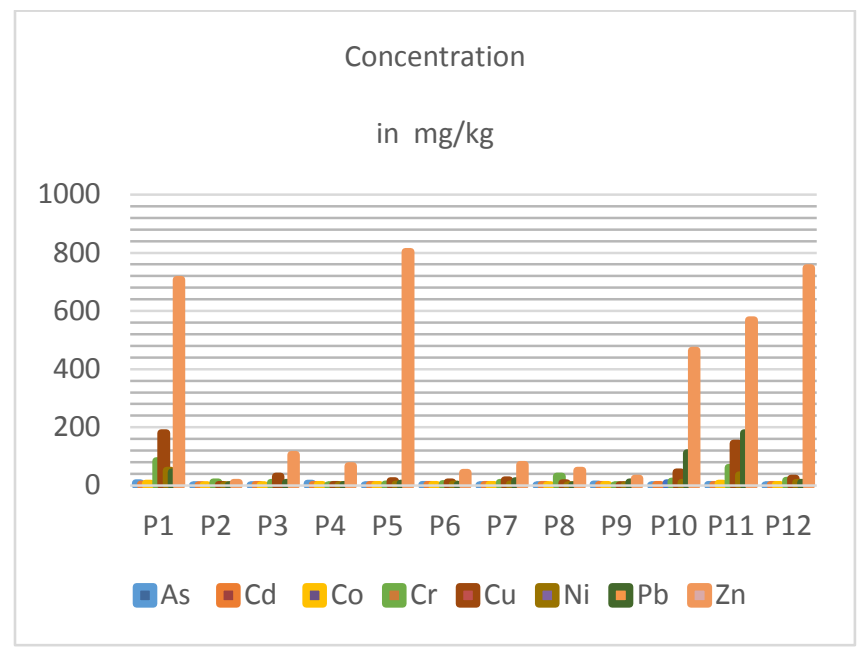

Fig. 4. Variation of heavy metal concentration in mosses collected samples

From the graph it can be seen that the highest concentrations of metals in the moss samples were obtained in the case of zinc and copper.

Table 4. Concentration range obtained for the analysed elements of mosses

\begin{tabular}{|c|c|c|c|}
\hline Elements & $\begin{array}{c}\text { Wavelength } \\
\mathbf{n m}\end{array}$ & $\begin{array}{c}\text { The concentration range } \\
\text { determined by elements in the } \\
\text { moss samples } \\
\mathbf{~ m g / k g}\end{array}$ & $\begin{array}{c}\text { The concentration range } \\
\text { determined by elements in the } \\
\text { soil samples } \\
\mathbf{~ m g / k g}\end{array}$ \\
\hline $\mathrm{As}$ & 199.696 & $0.026 \div 8.088$ & $0.041 \div 0.565$ \\
\hline $\mathrm{Cd}$ & 228.802 & $2.020 \div 4.119$ & $0.86 \div 2.2$ \\
\hline $\mathrm{Co}$ & 228.616 & $0.230 \div 6.545$ & $1.060 \div 17.38$ \\
\hline $\mathrm{Cr}$ & 267.716 & $0.126 \div 84.50$ & $0.020 \div 20.1$ \\
\hline $\mathrm{Cu}$ & 327.393 & $0.014 \div 180$ & $1.90 \div 26.76$ \\
\hline $\mathrm{Ni}$ & 231.604 & $0.371 \div 50.88$ & $0.198 \div 54.4$ \\
\hline $\mathrm{Pb}$ & 220.353 & $0.045 \div 18.09$ & $0.654 \div 4.775$ \\
\hline $\mathrm{Zn}$ & 213.857 & $9.197 \div 747.1$ & $8.248 \div 602$ \\
\hline
\end{tabular}




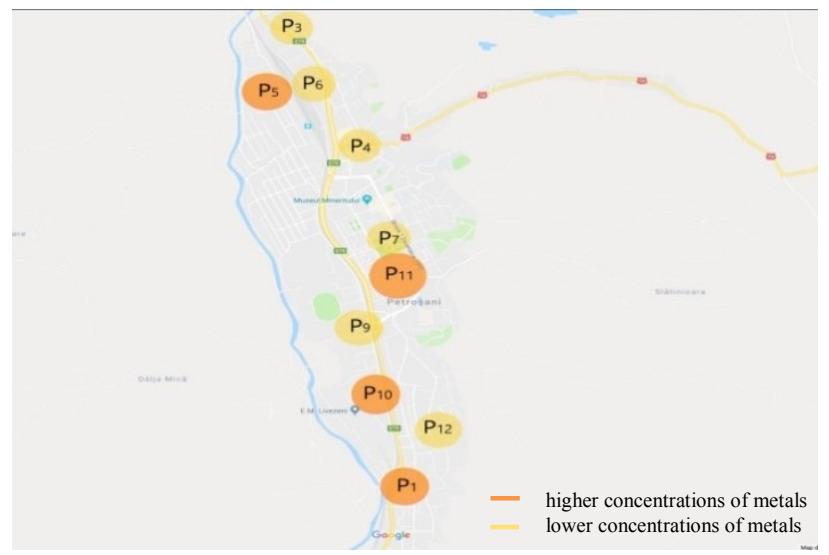

Fig. 5. Representation of areas according to concentrations of heavy metals in mosses

After analysing the moss samples were the sampling points on the map, where values of higher concentrations and moderate values were obtained, on the fig no. 5 .

Following the maximum values, we can conclude that the highest values for the metal concentrations determined by the ICP-OES method in moss were obtained for zinc, lead, copper, chromium, nickel, cobalt, arsenic and cadmium. the concentrations of the metals in the soil may be different from the metal content of the plants such as.

\section{Conclusions}

Considering the fact that there could not be established a quantitative relationship between the heavy metal content in soils and the heavy metal content determined in the moss samples, some conclusions can be drawn by comparing the trends. Concentration of metallic elements in moss samples exceeds the available metallic content of the soil. The lowest concentrations of heavy metals present in the moss's tissues correspond to unpolluted areas.

The content of heavy metals determined in the case of moss samples refers mainly to the atmospheric origin pollution (dry and wet sedimentation) and generated by precipitation. By examining the concentrations of metals determined by the analysis of the samples of moss, it can be observed that zinc is found in the highest concentration, and that it can be generated from burning of fossil fuels, but also from the wear of auto components.

Copper and lead are the following metals in terms of concentrations found in moss samples, which may come from burning fossil fuels, fuels, and component wear. The origin of the copper can also be explained by transport because the wear of the vehicle's brake pads release a large amount of metal. The values of the other metals $(\mathrm{Cr}, \mathrm{Co}, \mathrm{Ni}, \mathrm{Cd})$ found in the moss are lower, being generated from the processes of combustion and decomposition.

Cadmium concentration values are caused by cadmium-containing combustion products containing diesel fuel and the cadmium-containing stabilizing material of the tires. By comparing the spatial distribution of the highest metal concentrations, it can be concluded that the highest values come from the samples collected from areas where solid fuels are being used for heating up homes: the Colony, Dimitrov and the heavily affected areas of road and rail transport as well as the vicinity of mining units. The highest heavy metal concentrations in urban zones are related to high vehicular traffic and high emission of industrial pollutants. 
This paper was developed within the NUCLEU - Programme, carried out with the support of ANCSI, Project no. PN-19 210103.

\section{References}

1. Anicic M., Frontasyeva M., Tomasevic M., Popovic A., Assessment of atmospheric deposition of heavy metals and other elements in Belgrade using the moss biomonitoring technique and neutron activation analysis. Environ Monit Assess.;129(1-3):207-219, (2007).

2. Barandovski L., Frontasyeva M., Stafilov T., Šajn R., and Ostrovnaya T., "Multi-element atmospheric deposition in Macedonia studied by the moss biomonitoring technique," Environmental Science and Pollution Research, June. (2015).

3. Berg T., Royset O., Steinnes E., Vadset M., Atmospheric trace element deposition: principal component analysis of ICP-MS data from moss samples. Environ Pollut. ;88(1):67-77. doi: 10.1016/0269-7491(95)91049-Q, (1995).

4. Gaza T., Kugara J., Study of Heavy Metal Air Pollution, using a moss (Grimmia dissimulate) Biomonitoring Technique Universal Journal of Chemistry 6(1): 1-13, DOI: 10.13189/ujc.2018.060101, (2018).

5. Calamar A.N., Gaman G.A., Pupazan D., Toth L., Kovacs I., Analysis of environmental components by monitoring gas concentration in the environment, Environmental Engineering and Management Journal June Vol. 16, No. 6, 1249-1256, (2017).

6. Macedo-Miranda G., Avila-Pere P., Gil -Vargas G., Zarazua, J., Sanchez-Meza C., ZepedaGomez C., Tejeda S., Accumulation of heavy metals in mosses: A biomonitoring study Springerplus 2016, 5(1) :715, doi: 10.1186/S40064-016-2524-7, (2016).

7. Swaileh K.M., Rabay'a N., Salim R., Ezzughayyar A., Rabbo A.A.,: Concentrations of heavy metals in roadside soils, plants and land snails from the West Bank, Palestine. J. of Environmental Science and Health (Part A), 36 (5), 765-778, (2001).

8. Zepeda-Gómez C., Avila-Pérez P., Díaz-García U., Alanís Y., Zarazúa G., Amaya A., Diversidad de musgos epífitos de la Zona Metropolitana del Valle de Toluca México. Revista Mexicana de Biodiversidad.; 85:108. doi: 10.7550/rmb.35456 (2014).

9. Zhou X., Chen Q., Liu C., Fang Y., Using moss to access airborne heavy metal pollution in Taizhou, China Int J. Environ Res. Public Health. 20 Apr 17; 14(4). pii: E430. doi: 10.3390/ijerph14040430 (2017). 